\section{Public Health Genomics}

Public Health Genomics 2010;13:362-367

DOI: $\underline{10.1159 / 000272457}$
Received: February 2, 2009

Accepted after revision: August 4, 2009

Published online: December 29, 2009

\title{
Interleukin 10 Gene Polymorphisms and Development of Post Kala-Azar Dermal Leishmaniasis in a Selected Sudanese Population
}

\author{
S. Farouk ${ }^{a, b}$ M.A.Salih ${ }^{a} \quad$ A.M. Musa ${ }^{a} \quad$ J.M. Blackwell ${ }^{c}$ E.N. Miller ${ }^{c} \quad$ E.A. Khalil ${ }^{a}$ \\ A.M. ElHassan ${ }^{a}$ M.E. Ibrahim ${ }^{\text {a }}$ H.S. Mohamed ${ }^{a}$ \\ ${ }^{a}$ Institute of Endemic Diseases, University of Khartoum, and ${ }^{b}$ Faculty of Science and Technology, \\ Al-Neelain University, Khartoum, Sudan; ${ }^{c}$ Cambridge Institute for Medical Research, Cambridge, UK
}

\section{Key Words}

Genetic association • Interleukin $10 \cdot$ Leishmaniasis • Post

kala-azar dermal leishmaniasis

\begin{abstract}
Background: Post kala-azar dermal leishmaniasis (PKDL) is a cutaneous form of disease that develops at variable times after individuals have received treatment for clinical visceral leishmaniasis (VL). The study aimed to investigate the possible role of interleukin 10 (IL-10) and development of PKDL. Methods: 77 families composed of 41 complete case-parent trios and 36 case-parent pairs from the Masalit ethnic group were genotyped for 3 IL10 promoter polymorphisms: $-1082 \mathrm{~A} / \mathrm{G},-819 \mathrm{C} / \mathrm{T}$ and $-592 \mathrm{C} / \mathrm{A}$. Results: Single point analysis using the transmission disequilibrium test showed no evidence of association between any of these IL10 promoter single nucleotide polymorphisms (SNPs) and development of PKDL. Haplotype analysis performed using TRANSMIT showed borderline significance between PKDL and the haplotype AA across $-592 \mathrm{C} / \mathrm{A}$ and $-1082 \mathrm{~A} / \mathrm{G}(\mathrm{p}=0.053)$. Haplotypes GCC (0.33) and ATA (0.30) were the common haplotypes in this Sudanese population. Allele frequencies for the 3 SNPs differed significantly in Sudan compared to other African (Gambian, Malawian, YRI) populations. Conclusion:
\end{abstract}

There is no evidence for an association between 3 SNPs in the IL10 gene promoter and susceptibility to PKDL in the Masalit ethnic group in Sudan, although some evidence for haplotype association was observed.

Copyright $\odot 2009$ S. Karger AG, Basel

In Sudan post kala-azar dermal leishmaniasis (PKDL) is a known complication of visceral leishmaniasis (VL) caused by Leishmania donovani and occurs in some patients after treatment and cure of VL. PKDL occurs with a frequency of $56-62 \%$, usually after a latent phase from months to years $[1,2]$. Clinical characterization of the disease was previously described [3]. Experimental studies indicate that interleukin 10 (IL-10) plays an important regulatory role in the progression of VL. IL-10 was the most prominent cytokine in PKDL lesions [4] with high levels also observed in plasma [5]. However, interferon- $\gamma$ (IFN- $\gamma$ ) was also seen in all lesions [4] and was detected in keratinocytes and/or sweat glands of patients who developed PKDL. In response to leishmanial antigens, peripheral blood mononuclear cells from most Sudanese PKDL patients proliferate and produce IFN- $\gamma$ and IL-10 $[4,5]$. Silva et al. (1992) postulated that the presence of IL10 in the skin lesions could block the action of IFN- $\gamma$,

\section{KARGER}

Fax +41613061234

E-Mail karger@karger.ch

www.karger.com (c) 2009 S. Karger AG, Basel

Accessible online at: www.karger.com/phg
Dr. H.S. Mohamed

Institute of Endemic Diseases, University of Khartoum

P.O. Box 102, Khartoum (Sudan)

Tel. +249 912605 221, Fax +249 183779712

E-Mail HibaSalah@iend.org 
rather than inhibit its production [6]. In mice, IL-10 was found to play an important role in parasite persistence as sterile cure was detected in IL-10 deficient mice on a resistant genetic background [7]. Recently IL-10 was found to be strongly associated with development of ulcerated skin lesions in L. braziliensis infection in humans, supported by data showing genetic associations for single nucleotide polymorphisms (SNPs) across the IL10 gene and evidence that the $-819 \mathrm{C} / \mathrm{T}$ SNP in the IL10 promoter plays a functional role in determining binding of nuclear transcription factors and levels of IL10 gene expression [8].

In the present study we investigated the IL10 promoter polymorphisms $-1082 \mathrm{~A} / \mathrm{G},-819 \mathrm{C} / \mathrm{T}$, and $-592 \mathrm{C} / \mathrm{A}$. The importance of IL10 three selected polymorphisms has been documented in several disease processes by independent studies. The -592C/A SNP lies within negative regulatory elements in the promoter [9]. It has been shown that the $-592 \mathrm{C} / \mathrm{A}$ polymorphism is associated with diminished IL10 production [10]. Different studies reported the functional role of $-1082 \mathrm{~A} / \mathrm{G}$ polymorphisms. Turner et al. found that lymphocytes with the GG genotype responded with significantly enhanced IL-10 secretion compared to those with the AA genotype [11]. Another study showed high IL-10 plasma levels was associated with the $-1082 \mathrm{~A}$ allele in the Dutch population [12]. The -1082A allele was able to confer an increase in transcriptional activity of the $I L-10$ promoter [13]. The study presented here looked for association between these SNPs and the development of PKDL.

\section{Material and Methods}

Ethical approval for this study was obtained from the Institute of Endemic Diseases, University of Khartoum Ethical Committee. The study was conducted in the region of the Rahad River in Eastern Sudan where VL and PKDL are endemic. Samples were collected from individuals belonging to the Masalit tribe who are highly susceptible to VL and PKDL [14-16]. Trios with PKDL were ascertained from epidemiological and medical records of the Institute of Endemic Diseases. Diagnosis was made on the basis of clinical, parasitological and serological criteria as described previously [14, 17]. Epidemiological and demographic details relating to the study site are also described in detail elsewhere [14]. DNA was extracted from buccal swap samples and successfully genotyped for 77 families that composed of 41 complete caseparent trios and 36 case-parent pairs (i.e. one parent missing). Amplification refractory mutation system (ARMS-PCR) was employed to genotype the $-1082 \mathrm{~A} / \mathrm{G}$ (rs1800896) and $-819 \mathrm{C} / \mathrm{T}$ (rs1800871) using primers previously described [18] with specific sequence for both alleles, wild and mutant type and common primer. The $-1082 \mathrm{~A} / \mathrm{G}$ primers were: common $5^{\prime}$-cagtgccaactgagaatttgg- $3^{\prime}$; mutant type $5^{\prime}$-ctactaaggcttctttgggag- $3^{\prime}$; and wild type $5^{\prime}$-actactaaggcttctttgggaa- $3^{\prime}$ The $-819 \mathrm{C} / \mathrm{T}$ primers were: common $5^{\prime}$-aggatgtgttccaggctcct- $3^{\prime}$; mutant type $5^{\prime}$-acccttgtacaggtgatgtaat- $3^{\prime}$; and wild type $5^{\prime}$-cccttgtacaggtgatgtaac- $-3^{\prime}$. Human growth factor hormone primers were included in each PCR reaction as internal control: forward primer $5^{\prime}$-gccttcccaaccattccctta- ${ }^{\prime}$ and reverse primer $5^{\prime}$-tcacggatttctgttgttttc- ${ }^{\prime}$. ARMS PCR to detect the 2 polymorphisms $(-819 \mathrm{C} / \mathrm{T})$ and $(-1082 \mathrm{~A} / \mathrm{G})$ was carried out in a total volume of $10.5 \mu \mathrm{l}$ composed of; $1 \times$ Bioline PCR reaction buffer, $2 \mathrm{mM} \mathrm{MgCl} 2,10 \mathrm{~mm}$ dNTPs, 1 unit Taq polymerase, $10 \mu \mathrm{M}$ of each oligonucleotide, $0.5 \mu \mathrm{M}$ of internal control primers and $5 \mu \mathrm{l}$ of dd $\mathrm{H}_{2} \mathrm{O}$.

A touch down program was used as follows: denaturation at $96^{\circ} \mathrm{C}$ for $1 \mathrm{~min}, 9$ cycles contain denaturation at $96^{\circ} \mathrm{C}$ for $35 \mathrm{~s}$, annealing at $63^{\circ} \mathrm{C}$ for $45 \mathrm{~s}$ and elongation at $72^{\circ} \mathrm{C}$ for $35 \mathrm{~s}, 27 \mathrm{cycles}$ of denaturation at $96^{\circ} \mathrm{C}$ for $25 \mathrm{~s}$, annealing at $59^{\circ} \mathrm{C}$ for $50 \mathrm{~s}$ and elongation at $72^{\circ} \mathrm{C}$ for $40 \mathrm{~s}$. Finally 9 cycles comprising denaturation at $72^{\circ} \mathrm{C}$ for $5 \mathrm{~min}$, annealing at $55^{\circ} \mathrm{C}$ for $1 \mathrm{~min}$ and elongation at $72^{\circ} \mathrm{C}$ for $90 \mathrm{~s}$ were carried out. The PCR product was run in $2 \%$ agarose gel stained with ethidium bromide, visualized and photographed by gel documentation system. Genotype scoring was based on the presence or absence of target bands.

A restriction fragment length polymorphism (PCR-RFLP) was used to genotype the -592C/A (rs1800872) SNP, using forward primer $5^{\prime}$-ataaaatagagacggtaggg- $3^{\prime}$ and reverse primer $5^{\prime}$ ggctaaatatcctcaaagtt- $3^{\prime}$. The PCR reaction was carried out in a total volume $21.2 \mu \mathrm{l}$ composed of $1 \times$ Bioline PCR reaction buffer, $2 \mathrm{mM} \mathrm{MgCl}_{2}, 10 \mathrm{mM}$ dNTPs, 1 unit Taq polymerase, $10 \mu \mathrm{M}$ of each primers and $8.3 \mu \mathrm{l}$ of $\mathrm{dd} \mathrm{H}_{2} \mathrm{O}$. The PCR conditions were: denaturation at $95^{\circ} \mathrm{C}$ for $5 \mathrm{~min}, 35$ cycles of denaturation at $95^{\circ} \mathrm{C}$ for $30 \mathrm{~s}$, annealing at $57^{\circ} \mathrm{C}$ for $30 \mathrm{~s}$, elongation at $72^{\circ} \mathrm{C}$ for $45 \mathrm{~s}$ and final extension at $72^{\circ} \mathrm{C}$ for $10 \mathrm{~min}$. The PCR product was digested by $R s a \mathrm{I}$ restriction enzyme as for $3 \mathrm{~h}$ at $37^{\circ} \mathrm{C}$. The digested products were run in $2.5 \%$ agarose gel, stained with bromide, visualized and photographed by gel documentation system.

Deviation from Hardy-Weinberg Equilibrium (HWE) was determined using a set of unrelated individuals from the families (parents), excluding any with PKDL. Tests for HWE were performed within STATA 9.1 (http://www.stata.com/) using the GenAssoc package (http://www-gene.cimr.cam.ac.uk/clayton/ software/stata/). Tests for linkage disequilibrium (LD) between SNPs were performed using Haploview v3.32 (www.broad.mit. edu/mpg/haploview/). Single point and haplotype association tests (haplotype-based score tests) were performed using the transmission disequilibrium test (TDT) in the program TRANSMIT (http://www-gene.cimr.cam.ac.uk/clayton/software/) which takes account of missing parental genotype data. Genotype and allele frequencies in our study population were compared with other African groups, Mandinka, Wolf and Jola groups from Gambia [19], Bantu from Karonga district in Malawian [20], and the YRI HapMap data.

\section{Results}

Representative genotyping data for all 3 SNPs are shown in figures $1-3$. For the -592C/A SNP, a PCR product of $269 \mathrm{bp}$ is obtained (fig. 1). Digestion with RsaI restriction enzyme results in 2 bands for the mutant allele 
Fig. 1. -592C/A genotyping using PCRRLFP. Lanes 1, 2, 5, 9: heterozygous; lanes $3,6,8,10$ : homozygous for wild type allele (269 bp); lane 7: homozygous for mutant allele (201 bp and $68 \mathrm{bp}$ ). Lane 4 contains the 50 bp DNA molecular weight marker. Fig. 2. -819C/T genotyping using ARMSPCR. Lane 1: 50 bp DNA molecular weight marker. Lanes 2, 4, 6 and 8: allele $C$ is represented by the presence of a $233 \mathrm{bp}$ PCR fragment. Lanes 3, 5, 6 and 9: allele $\mathrm{T}$ is represented by the presence of a $233 \mathrm{bp}$ PCR fragment. Each two lanes represent one sample: lanes 2 and 3, homozygous (CC); lanes 4 and 5, heterozygous (CT); lanes 6 and 7, homozygous (TT); lanes 8 and 9, negative controls. Lanes 2-7: a 429 bp represents the amplified product of the Human Growth Factor Hormone gene (internal control).

Fig. 3. $-1082 \mathrm{~A} / \mathrm{G}$ genotyping using ARMSPCR. Lane 1: 50 bp DNA molecular weight marker. Lanes 2, 4, 6 and 8: allele A is represented by the presence of a $260 \mathrm{bp}$ PCR fragment. Lanes 3, 5, 6 and 9: allele $G$ is represented by the presence of a $260 \mathrm{bp}$ PCR fragment. Each two lanes represent one sample: lanes 2 and 3, homozygous (AA); lanes 4 and 5, heterozygous (AG); lanes 6 and 7, homozygous (GG); lanes 8 and 9, negative controls. Lanes 2-7, a 429 bp represents the amplified product of the Human Growth Factor Hormone gene (internal control).
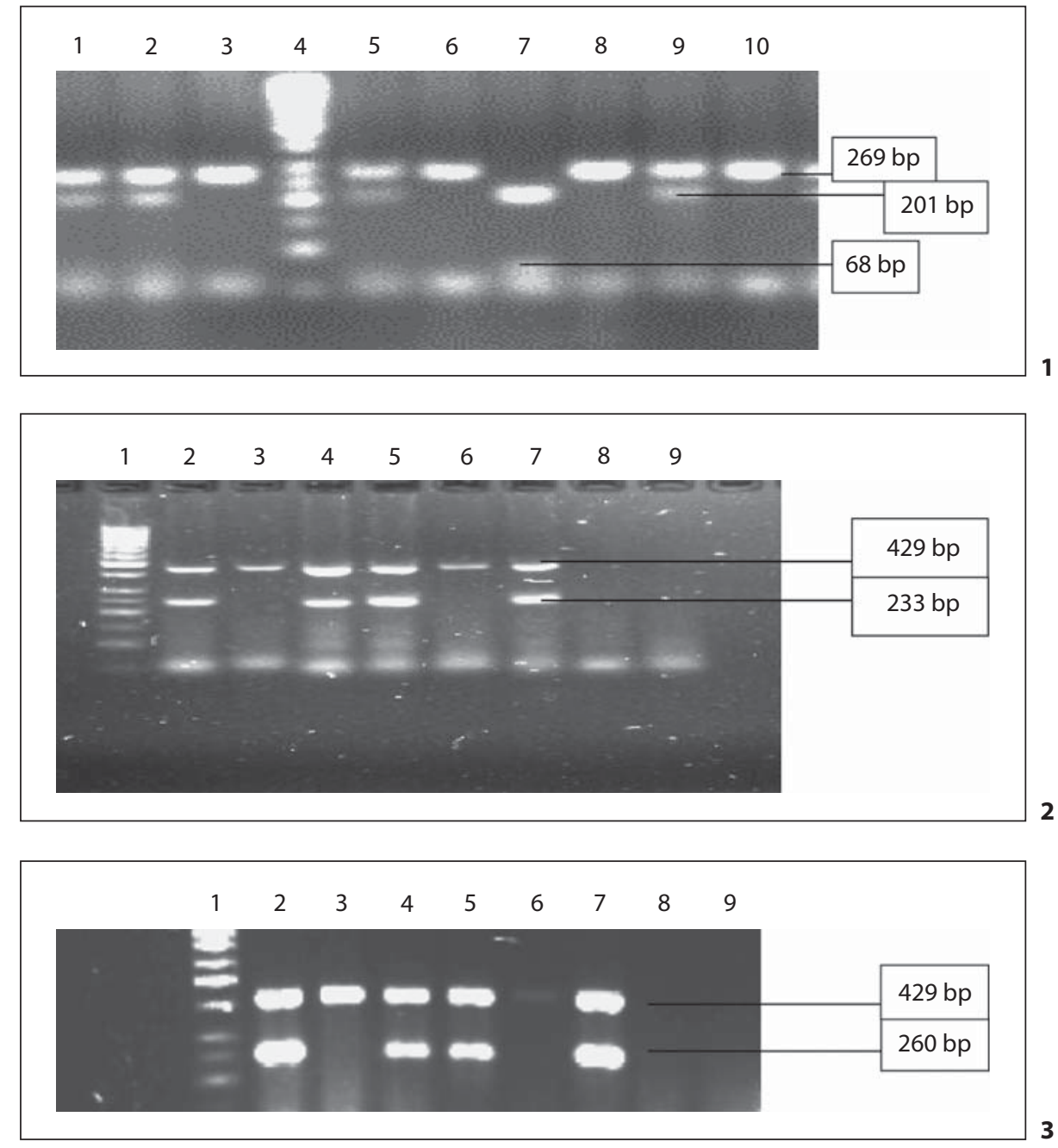

equivalent to $201 \mathrm{bp}$ and $68 \mathrm{bp}$, while the normal allele remains uncut ( $269 \mathrm{bp}$ ). The ARMS-PCR size bands from of IL10 -819C/T and IL10 -1082A/G were 233 bp and 260 bp respectively, while the internal control results in 429 bp (fig. 2, 3). All genotypes of the target IL10 polymorphisms were in Hardy-Weinberg equilibrium ( $p>0.05$ ). Frequencies for $-1082 \mathrm{~A},-819 \mathrm{C}$ and $-592 \mathrm{C}$ alleles in our study population were $48 \%, 47 \%$ and $50 \%$, respectively. There was no evidence for strong LD between different SNP pairs (D' range $0.47-0.63 ; \mathrm{r}^{2}$ range $0.20-0.35$ ).

The single point TDT carried out in TRANSMIT showed no evidence of association between promoter SNPs -1082A/G, -819C/T and -592C/A and development of PKDL $p>0.05$ (table 1). The haplotype-based score test in TRANSMIT showed borderline significance $(\mathrm{p}=0.05)$ for association between PKDL and the over-transmitted haplotype AA across the $-1082 \mathrm{~A} / \mathrm{G}$ and $-592 \mathrm{C} / \mathrm{A}$ SNPs (table 1; global $\chi^{2}=7.69 ; \mathrm{df}=3 ; \mathrm{p}=0.05$ ). In this population in Sudan, the GCC (33\%) and ATA (30\%) haplotypes were more frequent than other haplotypes across the 3 promoter SNPs (fig. 4). Whereas this Sudan population differed in allele frequency at the $-1082 \mathrm{~A} / \mathrm{G}$ SNP compared to Gambian [21], Malawian [20] and the HapMap YRI population (fig. 5), for the $-819 \mathrm{C} / \mathrm{T}$ and $-592 \mathrm{C} / \mathrm{A}$ SNPs it was the Malawian population that was at variance with Sudan and the other African populations.

\section{Discussion}

VL is an important health problem in the Sudan, but remains largely a neglected disease. There is neither effective drug nor vaccines available. PKDL patients were suspected to be a source for VL infection in Sudan. The 


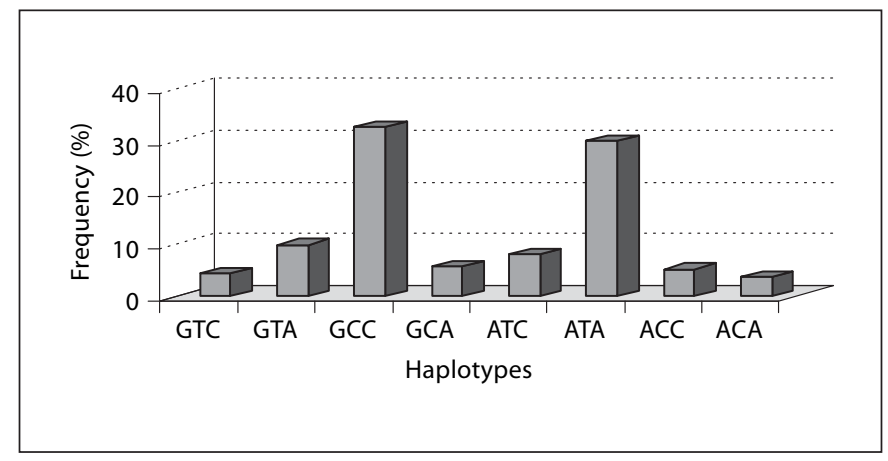

Fig. 4. Haplotype frequencies (-1082A/G, $-819 \mathrm{C} / \mathrm{T}$ and $-592 \mathrm{C} / \mathrm{A})$ for the IL10 gene polymorphisms in Sudan.

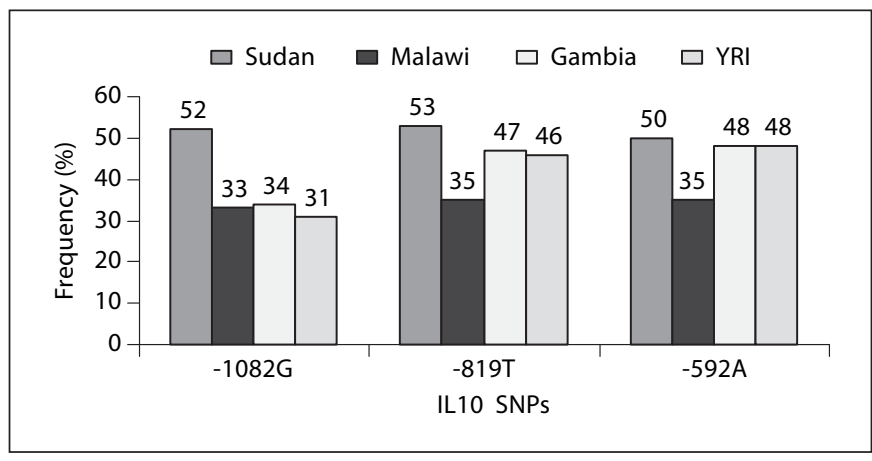

Fig. 5. Allele frequencies for the $-1082 \mathrm{G},-819 \mathrm{~T}$ and $-592 \mathrm{~A}$ alleles in different African populations including the HapMap YRI population.

Table 1. Results of association analyses

\begin{tabular}{|c|c|c|c|}
\hline Haplotype groups & $-1082 \mathrm{~A} / \mathrm{G}$ & $-819 \mathrm{C} / \mathrm{T}$ & $-592 \mathrm{C} / \mathrm{A}$ \\
\hline 2 markers & \multicolumn{3}{|c|}{$\chi^{2}=0.85 ; \mathrm{df}=3 ; \mathrm{p}=0.84$} \\
\hline 2 markers & \multicolumn{3}{|c|}{$\chi^{2}=3.09 ; \mathrm{df}=3 ; \mathrm{p}=0.38$} \\
\hline 2 markers & $\chi^{2}=7.69 ; \mathrm{df}=3 ; \mathrm{p}=\mathbf{0 . 0 5}$ & & $\chi^{2}=7.69 ; \mathrm{df}=3 ; \mathrm{p}=\mathbf{0 . 0 5}$ \\
\hline
\end{tabular}

Grey shading indicates the combinations of markers used in the haplotypes tested.

factors that determine development or not of PKDL are not well understood, but a Leishmania-specific cellular immune response seems to play a fundamental role in the final control of infection. This study may help to identify provide biomarkers for future disease surveillance and indicate possible avenues for immunotherapeutic intervention in clinical disease.

IL-10 and IFN- $\gamma$ mRNA are observed concurrently in lesions from patients with post-kala-azar dermal leishmaniasis (PKDL) that indicates the production of IL-10 during L. donovani infection, and suggests a role for this cytokine in the regulation of immune responsiveness during VL [22]. In spite of the role of IL-10 in parasite persistence and its expected function in disease promotion, there were no single point associations between the 3 target polymorphisms and development of PKDL in the Masalit population studied here. Borderline association (global $\chi^{2}=7.69 ; \mathrm{df}=3$; nominal $\mathrm{p}=0.05$ ) was observed between PKDL and haplotypes for the 2 outer markers $-1082 \mathrm{~A} / \mathrm{G}$ and $-592 \mathrm{C} / \mathrm{A}$. This could indicate that other functional SNPs in this region could be functional variants for an association with PKDL, or that there is a complex association that relies on interaction between different functional SNPs across the region. However, in the current study this association is not robust to correction for multiple testing and a larger sample size would be needed to confirm such an association. In a recent study of cutaneous leishmaniasis in Brazil, Salhi et al. found that production of IL-10 was strongly associated with development of ulcerated skin lesions in L. braziliensis infection [8]. Along with several SNPs within the IL10 gene, they found single point associations with promoter SNPs $-819 \mathrm{C} / \mathrm{T}$ and $-592 \mathrm{C} / \mathrm{A}$ that were robust to correction for multiple testing, but not with promoter SNP -1082A/G. Functional studies demonstrated that the -819C/T SNP in the IL10 promoter plays a functional role in determining binding of nuclear transcription factors and levels of IL10 gene expression. In other studies the $-1082 \mathrm{G}$ allele has been shown to be associ- 
ated with higher IL-10 levels than the -1082A allele [11], but this could relate to LD across the region with other functional SNPs. In the Masalit tribe LD was not strong across the 3 SNPs, in contrast to data from Spanish, Caucasian and Asians where high LD was detected. Complete LD between $-592 \mathrm{C} / \mathrm{A}$ and $-819 \mathrm{C} / \mathrm{T}$ have been observed in Asians $[23,24]$. Interestingly our study population showed higher frequency of the $-1082 \mathrm{G}$ allele than other African groups. In our study there was no measurement for cytokines to compare different genotypes with IL-10 level.

The 2 most frequent haplotypes in the Masalit population were GCC and ATA (fig. 4). Although not statistically significant, the ATA haplotype was over-transmitted to PKDL patients in our study population. In previous studies, the ATA haplotype was found to be associated with high plasma levels of IL-10 in Finish population [25, 26]. In another study a slight increase in IL10 transcriptional activity of the GCC haplotypes was observed [27]. The presence of other haplotypes, even in lower frequen$c y$, may be effective to differentiate between populations. We found the GTA haplotype to be $10 \%$ in Masalit which was previously described in Caucasian and Brazilian with $1 \%$ frequency [28]. The haplotype GTC, ATC and
ACA were found in Masalit with frequencies 4.3\%, 8\% and $6 \%$ respectively, while the same haplotypes were respectively $1 \%, 4 \%$ and $1 \%$ in Caucasian and were absent in Brazilians. In contrast the ACC frequency, however, was 5\% in Masalit and higher in Caucasian 29\% [28] and Japanese 28\% [29]. In this study the presence of rare haplotypes, in our population may indicate genetic heterogeneity of functional importance.

In conclusion there is no single point evidence for an association between 3 SNPs in the IL10 gene promoter and susceptibility to PKDL in the Masalit ethnic group in Sudan, although some evidence for haplotype association was observed. High frequencies of the previously identified high IL10 producing haplotypes GCC and ATA were present in the Masalit. Further work using larger samples size and a wider range of SNPs may help to elucidate the role of IL-10 in PKDL development.

\section{Acknowledgments}

We thank the people from Um Salala, El-Rugab and Ali Babiker for their participation in this work. This work was funded by The Wellcome Trust.

\section{References}

1 Zijlstra EE, El-Hassan AM: Leishmaniasis in Sudan. Post kala-azar dermal leishmaniasis. Trans R Soc Trop Med Hyg 2001;95:S1/59S1/76.

-2 Musa AM, Khalil EAG, Raheem MA, Zijlstra EE, Ibrahim ME, El-Hassan IM, Mukhtar MM, El-Hassan AM: The natural history of Sudanese post-kala-azar dermal leishmaniasis: clinical, immunological and prognostic features. Ann Trop Med Parasitol 2002;96: 765-772.

-3 El-Hassan AM, Ghalib H W, Zijlstra EE, Eltoum IA, Satti M, Ali MS, Ali HMA: Post kala-azar dermal leishmaniasis in the Sudan: clinical features, pathology and treatment. Trans R Soc Trop Med Hyg 1992;86:245248.

4 Ismail A, El-Hassan AM, Kemp K, Gasim S, Kadaru AE, Moller T, Kharazmi A, Thender T: Immunopathology of post kala-azar dermal leishmaniasis (PKDL): T-cell phenotypes and cytokines profile. J Pathol 1999; 189:615-622.

5 Gasim S, Elhassan AM, Khalil EAG, Ismail A, Kadarau AM, Kharazmi A, Thender TG: High levels of plasma IL-10 and expression of IL-10 by keratinocytes during visceral leishmaniasis predict subsequent development of post-kala-azar dermal leishmaniasis. Clin Exp Immunol 1998;111:64-69.
-6 Silva JS, Morrissey PJ, Grapstein KH, Mohler KM, Anderson D, Reed SJ: Interleukin 10 and interferon-gamma regulation of experimental Trypansoma cruzi infection. J Exp Med 1992;175:169-174.

7 Belkaid Y, Hoffmann KF, Mendez S, Kamhawi S, Udey MC, Wynn TA, Sacks DL: The role of interleukin (IL)-10 in the persistence of Leishmania major in the skin after healing and the therapeutic potential of anti-IL-10 receptor antibody for sterile cure. J Exp Med 2001;194:1497-1506.

8 Salhi A, Rodrigues VJ. Santoro F, Dessein H, Romano A, Castellano LR, Sertorio M, Rafati S, Chevillard C, Prata A, Alcaïs A, Argiro L, Dessein A: Immunological and genetic evidence for a crucial role of IL-10 in cutaneous lesions in humans infected with Leishmania braziliensis. J Immunol 2008; 180:6139-6148

-9 Kube D, Platzer C, von Knethen A, Straub H, Bohlen $\mathrm{H}$, Hafner M, Tesch $\mathrm{H}$ : Isolation of human IL10 promoter. Characterization of promoter activity in Burkitt's lymphoma cell lines. Cytokine 1995;7:1-7.

10 Rosenwasser LJ, Borish L: The rational behind promoter-based candidate gene studies (IL-4 and IL-10). Am J Respir Crit Care Med 1997;156:152-155.
-11 Turner DM, Williams DM, Sankaran D, Lazarus M, Sinnott PJ, Hutchinson IV: An investigation of polymorphism in the interleukin-10 gene promoter. Eur J Immunogenet. $1997 ; 24: 1-8$.

12 Huizinga TW, Keijsers V, Yanni G, Hall M, Ramage W, Lanchbury J, Pitzalis C, Drossaers-Bakker WK, Westendorp RG, Breedveld FC, Panayi G, Verweij CL: Are differences in interleukin 10 production associated with joint damage? Rheumatology 2000;39: 1180-1188.

13 Rees LE, Wood NA, Gillespie KM, Lai KN, Gaston K, Mathieson PW: The interleukin$10-1082$ G/A polymorphism: allele frequency in different populations and functional significance. Cell Mol Life Sci 2002;59:560569.

14 Zijlstra EE, El Hassan AM, Ismael A, Ghalib HW: Endemic kala-azar in eastern Sudan: longitudinal study on the incidence of clinical and subclinical infection and post-kalaazar dermal leishmaniasis. Am J Trop Med Hyg 1994;51:826-836.

- 15 El Hassan AM, Zilijstra EE, Ismael A, Ghalib HW: Recent observations on the epidemiology of kala-azar in the eastern and central states of The Sudan. Trop Geograph Med 1995;47:151-156 
16 Khalil EA, Zijlstra EE, Kager PA, El Hassan AM: Epidemiology and clinical manifestations of Leishmania donovani infection in two villages in an endemic area in eastern Sudan. Trop Med Int Health 2002;7:35-44.

17 Zijlstra EE, El-Hassan AM: Leishmaniasis in Sudan. Visceral leishmaniasis. Trans R Soc Trop Med Hyg 2001;95:S1/27-S1/58.

-18 Perrey C, Turner SJ, Pravica V, Howell WM, Hutchinson IV: ARMS-PCR methodologies to determine IL-10 TNF-alpha, TNF-beta and TGF-beta 1 gene polymorphisms. Transpl Immunol 1999;7:127-128.

19 Mozzato-Chamay N, Mahdi OS, Jallow O, Mabey DC, Bailey RL, Conway DJ: Polymorphisms in candidate genes and risk of scarring trachoma in a Chlamydia trachomatis endemic population. J Infect Dis 2000;182: 1545-1548.

20 Fitness J, Floyd S, Warndorff DK, Sichali L, Malema S, Crampin AC, Fine PE, Hill AV: Large-scale candidate gene study of leprosy susceptibility in the Karonga district of Northern Malawi. Am J Trop Med Hyg 2004; 71:330-340.
21 Natividad A, Wilson J, Koch O, Holland MJ, Rockett K, Faal N, Jallow O, Joof HM, Burton MJ, Alexander ND, Kwiatkowski DP, Mabey DC, Bailey RL: Risk of trachomatous scarring and trichiasis in Gambians varies with SNP haplotypes at the interferon-gamma and interleukin-10 loci. Genes Immun 2005; 6:332-340.

22 Ghalib HW, Piuvezam MR, Sheiky NW, Siddig M, Hashim FA, El-Hassan AM, Russo DM, Reed SG: Interleukin-10 production correlates with pathology in human Leishmania donovani infection. J Clin Invest 1993;92:324-329.

23 Shin HD, Park BL, Kim LH, Cheong HS, Lee IH, Park SK: Common interleukin 10 polymorphism associated with decreased risk of tuberculosis. Exp Mol Med 2005;37:128-132.

24 Tso HW, Ip WK, Chong WP, Tam CM, Chiang AKS, Lau Y: Association of interferon gamma and interleukin 10 genes with tuberculosis in Hong Kong Chinese. Genes Immun 2005;6:358-363.

25 Helminen M, Lahdenpohja N, Hurme M: Polymorphism of the interleukin-10 gene is associated with susceptibility to EpsteinBarr virus infection. J Infect Dis 1999;180: 496-499.
26 Kilpinen S, Huhtala H, Hurme M: The combination of the interleukin-1alpha (IL-1alpha-889) genotype and the interleukin-10 (IL-10 ATA) haplotype is associated with increased interleukin-10 (IL-10) plasma levels in healthy individuals. Eur Cytokine Netw 2002;13:66-71.

27 Crawley E, Kay R, Sillibourne J, Patel P, Hutchinson I, Woo P: Polymorphic haplotypes of the interleukin-10 5 ' flanking region determine variable interleukin-10 transcription and are associated with particular phenotypes of juvenile rheumatoid arthritis. Arthritis Rheum 1999;42:1101-1108.

28 Scarel-Caminaga RM, Trevilatto PC, Souza AP, Brito RB, Camargo LEA, Line SRP: Interleukin 10 gene promoter polymorphisms are associated with chronic periodontitis. J Clin Periodontol 2004;31:443-448.

29 Ide A, Kawasaki E, Abiru N, Sun F, Takahashi R, Kuwahara R, Fujita N, Kita A, Oshima K, Sakamaki H, Uotani S, Yamasaki H, YamaguchiY, Eguchi K: Genetic association between interleukin-10 gene promoter region polymorphisms and type 1 diabetes age-at-onset. Hum immunol 2002;63:690695

\title{
Erratum
}

In the article by De Marco 'Views on Personalized Medicine: Do the Attitudes of African American and White Prescription Drug Consumers Differ?' (Public Health Genomics 2010;13:276-283) the co-authors have been erroneously left out. Below all authors are listed:

\author{
Molly De Marco ${ }^{a}$ Sam Cykert ${ }^{b}$ Nettie Coad ${ }^{c}$ Kay Doost ${ }^{c}$ \\ Jennifer Schaal ${ }^{c}$ Brandolyn White ${ }^{d}$ Deborah Young ${ }^{d}$ \\ Malika Roman Isler a Giselle Corbie-Smith ${ }^{\mathrm{e}}$ \\ ${ }^{a}$ Health Disparities Program, Cecil G. Sheps Center for Health Services Research, \\ University of North Carolina, Chapel Hill, N.C., ${ }^{b}$ Moses Cone Health Center, \\ Greensboro, N.C., and the Cecil G. Sheps Center for Health Services Research, \\ University of North Carolina, Chapel Hill, N.C., ' Greensboro Health Disparities \\ Collaborative, Greensboro, N.C., dUniversity of North Carolina Center for Community and \\ Clinical Research, Greensboro Area Health Education Center (AHEC), Greensboro, N.C., \\ eHealth Disparities Program, Cecil G. Sheps Center for Health Services Research, \\ the North Carolina TraCS Institute, Community Engagement Core, the Gillings School \\ of Global Public Health, and the School of Medicine, University of North Carolina, \\ Chapel Hill, N.C., USA
}

Interleukin 10 Gene Polymorphisms and Development of PKDL 